\title{
The Journey of Skiing: Starting from the Altay Region Extending to the Winter Olympic Games
}

\author{
${ }^{1}$ İmdat Yarım*, ${ }^{1}$ Ebru Çetin, ${ }^{2}$ Birgül Güngör Orman \\ ${ }^{1}$ Sports Sciences Faculty, Gazi University, 06560 Ankara, Turkey. ${ }^{2}$ Institute of Turkish Revolution History, \\ Ankara University, Ankara, Turkey.
}

Submitted 25 June 2020; Accepted in final form 26 September 2020.

\begin{abstract}
Background. The skiing was first used in the history of mankind for transportation and hunting in the Altay Mountains, where harsh and long winter conditions exist. The use of skiing continued in many cultures and eventually turned into a sport where not the Winter Olympic Games serve as a venue for the competition. Objectives. This review aims to outline the phases of skiing and highlight how it started as means of transportation and hunting vehicle in nomadic Turkic tribes in the Altay region to meet the vital needs of the people and continued to develop as a sport during the thousands of years of adventure until the Winter Olympic Games and the cultural importance of ski in the nomadic Turkic tribes in the Altay Region. Methods. In the first stage of the study, the journey of two pieces of wood (ski) is analyzed, which were invented even before the wheel. In the second phase, we analyzed the technical development of this invention and its use during the wars. In the third phase, we examined how ski transformed into a sports branch and different disciplines. Results. In the researchers examined in the study, it has been mentioned that skiing starts from the vital need point and spread through migration and then used as a means of transportation and war. Attention has been drawn to the journey of rapidly spreading skiing into a modern Olympic sport. Today, skiing has become a sports branch and tourism which is made in large masses in the world. Conclusion. Skiing started from the vital need point by the nomadic Turkic tribes. The use of skies spread through migration and then used as a means of transportation and war. Thanks to this long journey of two pieces of wood, it has an essential place in the world in terms of economy, tourism, and sports.
\end{abstract}

KEYWORDS: Skiing, Altay Region, History of Skiing.

\section{INTRODUCTION}

The history of skiing is one of the important areas that have been scientifically researched in the world. The research about the history of skiing and skis date almost a hundred years back to 1926. In those years, 275 pieces of skiing were found in the excavations carried out in Finland and Russia. Analysis of the old ski parts found at these sites revealed a lot of information about the history of skiing and its purposes and the structure of which it was used. According to some researchers, the story of the ski material probably dates back to 20,000 years. According to them, skiing is a means of transportation even older than the wheel, and its origin is connected with the emergence of modern man (1).

According to historical evidence, the ski is the invention of communities living in Altaic and Siberia $(2,3)$. Chinese dynastic resources indicate that the three tribes of Mu-Ma Turks used their skis expertly during the war. Some experts consider descriptions of their skills in skiing as the first use of the technique in skiing $(1,4)$. This art, which continues its use and development within the dynamics of everyday life, was brought

*. Corresponding Author:

İmdat Yarım, Associate Professor

E-mail: imdatyarim@gmail.com 
to Europe by the Finnish tribes immediately after the migration from that region (5).

Studies from the Hess (1937) revealed that the origin of the word "ski" was not Scandinavian but a word taken from the regions of Finland (6). As a matter of fact, the name of the people of Lapp neighboring the Finns was recorded in the form of "Prokopis" as "skrithiphinno", one of the Greek historians who lived in the 6th century and in the form of Jordanes as "screedfennea," who wrote the history of the Goths. Both mean "skier Finns" (7). It is known that skiing was used in the wars in Scandinavia, and even it was used as a means of transportation during the war between Denmark and Finns in 1199 (8)). According to the information in the Scandinavian literature and obtained from Chinese sources, it has been documented in many types of research that the Finns learned skiing from "the Turks with wooden feet" and migrated it to Europe, especially to North Germany $(3,9,10)$.

The skiing, which began to spread in the Scandinavian countries, began to become a fun and sport rather than being used for war purposes. As an entertainment and leisure activity among the public, ski jumping and ski running branches emerged and became widespread (11) After the $1500 \mathrm{AD}$, three names were pioneered in the process of turning skiing activities into a sport branch, diverging to different branches and organizing competition organizations. These three names are Norheim, Nansen and Zdarsky, which contributed most to the development of Alpine discipline, were the most influential names in the journey to the Olympic Winter Games $(1,5)$. In the study, this long journey of skiing sports has been asked to be addressed with the main lines how it started as means of transportation and hunting vehicle in nomadic Turkic tribes in the Altay region to meet the vital needs of the people and continued to develop as a sport during the thousands of years of adventure until the Winter Olympic Games. It can be said that more vital needs are taken into consideration in the research. it is tried to explain the process of transforming the ski material, which still preserves its first form. $(1,12)$.

\section{MATERIAL AND METHODS}

The scientific modality adopted in this study; Based on the data obtained by using literature scanning and data collection techniques related to the subject to be researched. In this research has been in the form of evaluating the arguments put forward in the literature by supporting or discussing them from different aspects.

In the first stage of the study, the journey of two pieces of wood (ski) is analysed, which were invented even before the wheel. In the second phase, the technical development of this invention and its use during the wars is discussed. In the third phase, how the use of ski transformed into a sports branch, and into different disciplines is examined.

History of Skiing and Ski Before Christ (BC). In Kazakhstan, China and Mongolia, rock paintings (pictograph) were examined and the skier figures were claimed to date back to 20,000 10,000 B.C. however, it is also controversial whether there is sufficient scientific evidence on this subject. The oldest ski equipment in the world dates back to 6300-5700 BC. These materials were found in the excavations in Russia near Sindor Lake, $1200 \mathrm{~km}$ northwest of Moscow, in 1965 (9, 12, 13). At the same time, this ski equipment has passed on to human history as the oldest sports material known in the World (15). Following this, "Hoting Ski" which dates back to 4500 BC was found in Sweden in 1927 BC, "Kalvatrask Ski" belonging to 3623-3110 BC, and 1 baton was found in Sweden in 1924The "Salla ski" belonging to 3345-3145 BC were found in Finland in 1938. "Drevja ski" belongs to 3345-2939 BC in Norway and the first binding dated to 206-25 BC was found in Chinese written sources. "Rihiimaki ski" belonging to 257-3 BC was found in Finland in 1928 (14).

According to the information obtained as a result of the examination of the rock paintings in Altay region, the ski material was found in the first rock painting of 20000-10000 years BC (15) (Figure 1, Figure 2). In Ural-Altay region, it is known that human societies used skiing as a hunting tool (14). This situation, as a result of recent research, the main field of the Turks spread, between the Altay-Ural mountains and the northeast plains of the Caspian Sea, considering that the communities in these depictions, were the ancestors of Turkic Tribes (16).

Early archaeological finds indicate that the oldest Turkish communities lived in the northwest region of the Altay-Sayan Mountains since the early ages of the Stone Age (17). In addition, Ögel mentions that a tribe of Oghuz type or Azilien races lived in the Altay Mountains in 3000 BC (18). The most important economic activity in the snow-covered Siberian forests was hunting. 
When skiing was first invented, there is no doubt that there was a real revolution in the Tayga Mountains between the art of hunting and those who survived. Because it is impossible to do winter hunting in these mountains without skiing. In addition to hunting, reindeer herds and herds in the region contributed to the development of the economy and trade. The Turks living in the region must have worked on ski technology as a natural necessity to defeat reindeer which is the most important economic value of the region. In Chinese sources, it is mentioned that in the $1000 \mathrm{~s}$ $\mathrm{BC}$ the Turks put a special vehicle on their knees to slide down on the snow and they graze their herds in this way $(12,16,19)$.

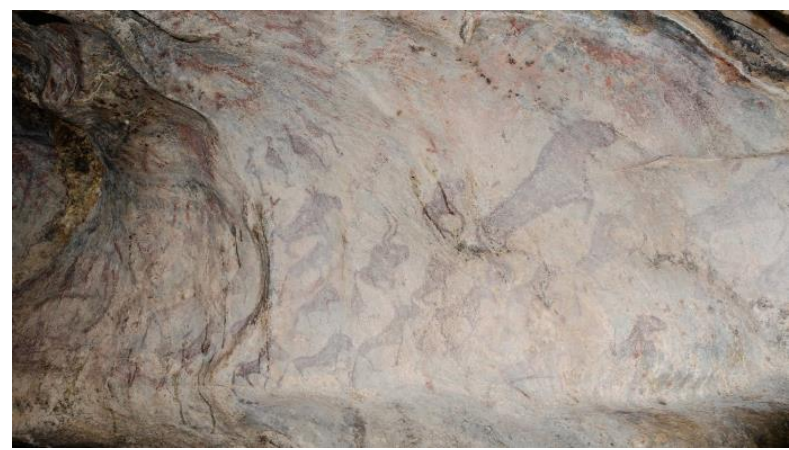

Figure 1. Rock Painting of Altai Hunters and Shepherds (13).

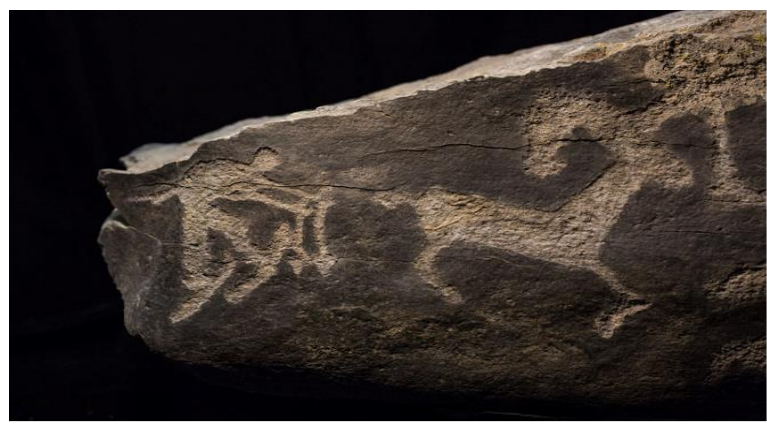

Figure 2. Rock Painting of Altai hunters (13)

The culture of Shepheretics born in Hunter culture has been domestics of reindeer and dogs. Feeding according to seasons is one of the determining factors of Shepherd culture $(12,16)$. The presence of skied shepherds can also be seen in some rock paintings. With the transition to shepherd culture, feeding of animals has started to be vital. Journeys and migrations have started to find green pastures for the animals to survive (16).

It is known that a tribe of Hun used skis to hunt deer in heavy winter conditions in the region where they live and they are thought to be one of
Turkic Tribes (20). In the "Shan-Hai-Ching" (Mountain and Sea information) of $350 \mathrm{BC}$, information about "Ting-Ling" is provided and there is an expression of "horse-footed" which is depicted as a horse in the upper side of the human being. It is also noted that they move quickly by connecting the board to their feet at the same source. The expression "wooden leg Turks" is referred to as "Muma Tukya" in this source. The aforementioned source is the oldest resource ever written about skiing, even in a symbolic way (12, 14). Besides these, Ögel has been expressed, referring to the history of Kyrgyz, "some Gokturk tribes in the east of Kyrgyzstan used skiing in winter, for this reason, the Chinese have named these tribes "Gokturks with wooden horse" (18).

Today, the word "ski" is derived from the root, which is used as "Skiö" in Norwegian and refers to two pieces of wood (5). On the other hand, the word "skidh", which means "ski" in Norwegian, a tree chip and a piece of wood, is also the same root as the word "Scheit" in German. In Finnish the word "suksi" comes from the same root (21). However, from an etymological point of view, the traditions and information related into the use of skiing in the languages of the Turkish communities in the Ural-Altaic language group, which also includes Turkish, dated to the past as a local one (12). As a matter of fact, the origin and naming of the ski is also a point to confirm this claim. Each ethnological material also creates a culture around it, and it is seen that a name is given to the tool that creates this culture. Societies which subsequently take the same vehicle or technology use the word as a cultural language heirloom according to their language characteristics (22).

As for the word "çana" used to refer to the phenomenon of skiing, this invention has a great importance for the history of civilization. The origin of the word is Turkish and Mongolian, but has been accepted by recent studies. In the Altay, Tilevut and Kuz dialects, the ski known as "Çana" and "Çanka". This word was used as "Sanga" in Bashkortes, "Tsanga" in Barabas, and "Sannka" in Kamchadalas which is far away (23). On the other hand, Kasgari gives the word "Çanka" in the meaning of skiing as a philological evidence for this word (24).

One of the two important things that Turks have brought to civilization is the domestication of the horse and the other is the use of iron in the horse's competence as a means of transportation. 
However, the migration of Turkish migrants to the west and the establishment of different political institutions forced them to create new Turkish cultural circles. The Turks also received some things from the peoples they had to live together in different geographies and gave them many things (20). Ski and skiing are examples of this. According to Chinese sources, skiing was not used in any tribe other than Turks and Mongols. It is understood that even the Chinese themselves do not know (22).

Basmiller, one of the communities living in the north of China in the studies on skiing in Central Asia in the First and Middle Ages, is saying that because the countries are very snowy, they make horse from wood and follow the deer by sliding on the snow. It is estimated that "Woden Horses" means "Woden Skii". These skis are similar in form to shield, with curved up front and underside of horse skin (used as wax today) to prevent slippage when climbing up. This material is also said to be worn as a shoe. This material is also said to be worn as a shoe (25). Today, this ski shape and ski discipline, which still maintains its form, has become the focus of the researchers. Renowned Turkish historical expert, Eberhard examined Chinese sources and conducted a research on the Asian Hun Empire (318-303 BC), he examined skiing in Turkish tribes and made a research about "Sports in Turks and Neighbors According to Chinese Sources". In the same years, another scientist Velidi Togan has done other work called "Skiing in Ancient Turks" (22).

History of Skiing and Ski After Christ (Anno Domini-AD). It is known that After Christ use of skiing in the Turkish States continued in Hun tribes, Ting-Lingler, Ba-ye-gular, Ba-himiler, Bo-malar, Mu-ma tribe from Göktürk tribes, Kyrgyz, other Göktürk tribes, Şorluks, Kimek State, İtil -Bulgarian State and Karahanlı State. In this historical process, we can say that the Mongols were affected by the Göktürk tribes, the Russians by the Shor Turks, and the Finns by the Itil-Bulgarian State. It was also known that skiing, which was used in hunting and transportation until the 1500 s, was used in the battles of Turks, Suomis, Mongols, Russians and Finns (7).

In 1483, the Russian army first took part in skied units against Sweden (26). Skiing used for military purposes between the years of 1500-1700 and the first rules have been used in the army (27).
In 1673 , the first binding of the shoe is attached to the heel of the ski is written in the source named lapponia (26). The apparent emergence of the ski branch as a sport took place in Central Europe, especially German physical educator Johann Christoph Friedrich GutsMuths (1759-1839) gave skiing training for children in schools and this ski sport was among the first mass activities. Afterwards, farmers in Slovenia, Austria and Germany also used it, and the skiing sport continued to flourish in these regions (28).

Development of Technique in Skiing. From the point of view of skiing techniques "telemark" is known as the basic technique of skiing. The ski and baton used in the Altay region are strongly likely to form the basis of this technique. In Norway, Sondre Norheim and his brothers developed this technique and used the skiing in their commercial activities for farming at the highest level. They also contributed to the development of skiing and binding used in Telemark technique. Also, the first information about skateboarding goes back to 1860 . In those years, the 30.5-meter jump of Sondre Nordheim was an important agenda. In the same years, it is seen that ski sports spread rapidly from Australia to New Zealand and the United States (29).

In particular, it is known that the groups migrating to America as gold mining workers from Scandinavia used ski in the mines to move faster and increase efficiency. Migration of Norwegian Sondre Nordheim to America, a pioneer in skiing, ski jumping and ski equipment, was also influential in this development (30).

First Ski Competitions in History. In the history of skiing competitions, the Norwegian King Harald III, who lived between 1015-1066 has an important place. In order to save his kidnapped son, he was able to search for fastmoving skiers on snow-covered grounds and even rewarded for this search. The first ski competition in the history of this search has the "Birkerbeiner Race" feature. His son was rescued by skiers, and this $50 \mathrm{~km}$ search route has been regularly used in competitions every year from 1932 to this time (26). Today, another prestigious and historical competition as much as the Winter Olympic Games and World Championships is asal "Vasaloppet". This competition is very important for the history of Sweden and is made to commemorate the victory of Gustav Eriksson Vasa and his troops, who won against the Danals in 1523 (27). The first official competition 
organization was held in 1922. The competitions which are $90 \mathrm{~km}$ long, are extremely important in terms of the history of the World Ski Sport. From 1922 to 1954, there were no winners except Swedish. Today, this competition, which is held every year in the first week of March, has become one of the top competitions and is still in progress (31).

The development of skiing in Europe has been rapid. In 1888, the Norwegian explorer and scientist Fridtjof Nansen managed to cross the $600 \mathrm{~km}$ Gronland by skiing in 40 days. The book written by Nansen after this discovery has aroused great interest in the world. This book is translated into German, English and French (5). The development of skiing in Europe has been rapid. In 1888, the Norwegian explorer and scientist Fridtjof Nansen managed to pass the 600 $\mathrm{km}$ Gronland by skiing in 40 days. The book written by Nansen after this discovery has aroused great interest in the world. This book is translated into German, English and French. The first winter sports club was established in Germany in 1892. In 1893, German Laurentius Urdahl published his first book "How to Learn Skiing". In 1902, the Holmelkollen races, which still continue today, began to be held. Afterwards, club structures continued to accelerate in Munich, Austria and Hungary. Developments in the name of skiing in the world continued in 1892 by organizing the "World Ski Equipment Exhibition". These developments have led to the increase of ski competitions. However, there have been major problems with the rules in competition organizations and the rules of cycling competitions have been referred to in order to remedy these problems $(5,28)$. The three people who are considered as the pioneers in the modern history of skiing are "Norheim", "Nansen" and "Zdarsky". While "Norheim" and "Nansen" contributed greatly to the development and spread of modern skiing, especially in the development of ski competitions "Zardarsky" contributed the most important contribution $(1,28)$.

Mathias Zdarsky and Transition to Modern Skiing. Mathias Zdarsky was born on February 25, 1856 in the German-speaking Moravia of the Czech Republic. In 1889, at the age of 33, he settled in Lilienfeld in the Austrian Alps. In this period Zdarsky took inspiration from the Norwegian Nansen's and ordered skiing from Norway and took the first step towards Alpine discipline, one of the most important sport branches in the field of skiing. Zdarsky has made changes to skiing and binding forms to overcome the difficulty of skiing in alpine and steep terrain in the Alps, on the contrary to the flat terrain in the Iskandinav regions, with a ski which he acquired from Norway (29) (1Allen). In this period, foundations for skiing and using different materials in Alpine skiing were laid. Unlike the ski running and telemark technique, Zdarsky has developed a new technique, the snow-sling and rotation (stem-kristania), which allows the skiing shoe to be fixed from the nose and heel parts to the ski with the help of clamping. Zdarsky developed a single baton for turning and slowing down in his landing technique (28)). The skibinding, shorter skiing and this new sliding technique are a new breakthrough in skiing, which is crucial for fast and safe sliding down the steep terrain of the Alpine rock (13).

In 1872, Zdarsky developed a shorter, narrower and thinner new ski form, replacing the "Lapp-ski", called the Suomi ski, which he saw in Norway. In addition to this, Norheim's binding, the shoe is attached with only one tie from the nose of the ski, with Zdarsky the shape of a mechanical attachment has gained modern structure. It also owns the first production and patent by producing 200 pairs of binds. In 1896 , the book published by Zdarsky describes this new technique. This technique was taught by Zdarsky and was widely used in Alpine mountains (13, $14)$.

The next major development is the use of the slalom technique to descend through the gates on turns. The activity, which was first built in 1905 by placing 85 gates on a 500-meter track, became the basis of today's slalom competitions. This was the first competition of Alpine discipline and was organised by the "His Alpine Ski Association", the largest ski association in Europe. Zdarsky died on June 20, 1940, at the age of 84 in St. Petersburg. Zdarsky, who owns the nickname of "The father of Alpine skiing", was the pioneer of today's ski sector by developing a ski branch of millions today $(13,28)$.

Ski Competitions Journey to the Winter Olympic Games. With the expansion of the clubs in central Europe, the increase in the ski competitions and technological development, ski sport has continued to spread at a great rate throughout the world. The first national ski associations were established in 1902 Germany, 1903 England, 1904 Switzerland, 1905 America, 
1906 Finland, 1908 Norway, Sweden and Italy. After the national events, there was a serious competition between Scandinavian and European countries in order to dominate the international competitions and this branch $13,(14,30)$.

Historically, the idea of Olympism emerges as a philosophy of life and culture in ancient Greece. The birth and philosophy of the Modern Olympics was born with the work of Baron Pierre de Coubertin. In 1894 Coubertin addressed the world as follows: "It may be a utopian thought to want people to love each other. But if we start organizing the Olympic Games once every 4 years, those who meet on this occasion can learn to respect each other to a minimum." The sport of Olympic philosophy with the theme of peace and love has been regarded as an encouraging role in the creation of a peaceful society that meticulously protects human dignity $(19,31)$.

After the 1896 Summer Olympic Games, the first organization in winter sports started in Europe in the 1900s under the name of "Ski Week" (29). Nordic Games and Holmenkollen participated in these organizations in Scandinavian countries. Europe and Scandinavia, which have made the world's most important ski competitions in their geographies, have transformed these competitions into serious and regular activities organized every four years. During the Holmenkollen competitions on February 18, 1910, the first "International Ski Commission" was held with the participation of 22 delegates and 10 countries. Austria, Finland, France, Germany, Great Britain, Spain and Switzerland joined. Russia, Italy and the United States did not participate but approved the decisions. The International Ski Commission held 8 meetings until 1924. The meetings and competitions held on February 2, 1924 within the scope of "International Winter Sports Week" with the participation of 36 delegates and 14 countries, became the foundation of FIS (International Ski Federation) and the first Winter Olympic Games. This decision was taken at the IOC (International Olympic Committee) meeting in Lisbon in 1926 $(1,2,29)$.

\section{CONCLUSION}

As a result of vital needs, skiing in the Altay has taken its place in the history of mankind for the purpose of transportation and hunting in the first snowy regions where there is a difficult winter season. Before the use of horses and the iron for transportation, it is said that the ski invented by Turks in Siberia and the Altay region has a great contribution to civilization. Considering the rock paintings examined in Kazakhistan, China, and Mongolia, it is thought that skiing has a history dating back to $20.000 \mathrm{BC}$ in world history. The present documents point to the Turks as both the origin of the word and the birth of the geography and tribe. Because of the emigration, it has spread all over the world, primarily to Russia, to Scandinavian countries, Europe, and the United States. The skiing used during transportation, hunting, and war has become increasingly widespread. Firstly, in the researches examined in the study, it has been mentioned that skiing starts from the vital need point and spread through migration and then used as a means of transportation and war. Finally, attention has been drawn to the journey of rapidly spreading skiing into a modern Olympic sport. Today, skiing has become a sports branch and tourism which is made in large masses in the world. "Fridtjof Nansen", "Sondre Nordheim" and "Mathias Zardsky"; are three important names for this sporting development and the reach of the masses. Nansen has introduced this material to the world by using the ski expedition and by converting it into a book in different languages. The Norwegian miner Nordheim moved to America and made a great contribution to material technology by producing both the first ski shoe and the transfer of skiing to a different continent. Zdarsky has made significant efforts in the spread of skiing in Europe, the emergence of a new ski style called Alpine discipline, and the formation of the form of ski binding technology.

By the 1900s, clubs in both Scandinavia and Europe began to be established, and instead of being used in skiing, hunting, and wars, they took on a new form for recreation and sport. In the north, especially in Sweden, Norway, and Finland, Nordic discipline competitions, and in Europe, especially in countries such as Germany, Austria, France, Italy, and Switzerland, Alpine discipline competitions have increased their popularity every day. Organizations between these countries have been organized regularly and gained speed in international competition. There have been serious rivalries between Scandinavian and European countries in the field of the organization. International competitions with high participation; it was organized as "Holmenkollen Competitions" in Scandinavia and "International Winter Sports Week" in 
Europe. These competitions have led to the emergence of the Winter Olympic Games after many international meetings.

In this study, only the development of skiing sport has been considered as a priority. The origins and technologies of skiing and related biathlon, ice skating, sled, etc. and other Olympic winter sports have not been explained enough. Considering that these sports branches are spread by a similar migration process, it can be suggested to investigate the history of different Olympic winter sports with different aspects. Skiing started from the vital need point by the nomadic Turkic tribes in the Altay region. The use of the ski which is one of the most important inventions of its age spread through migration and then used as a means of transportation and war. Thanks to this long journey of two pieces of wood, it has an important place in the world in terms of economy, tourism, and sports.

\section{APPLICABLE REMARKS}

- Thanks to this long journey of two pieces of wood, it has an important place in the world in terms of economy, tourism, and sports. No matter how much ski technology developed, we can see that skiing, which is the invention of the Turks, still preserves its first form today.

\section{CONFLICT OF INTEREST}

The authors report no conflicts of interest. The authors alone are responsible for the content and writing of the paper.

\section{REFERENCES}

1. Huntford R. Two planks and a passion: The dramatic history of skiing, Printed by MPG Books Ltd, Cornwall UK2009.

2. Krüger A. The history of the Olympic Games, the invention of tradition, In M. Goksøyr, G. von der Lippe \& K. Mo (Eds.). Sankt Augustion: Winter Games, Warm Traditions, Academia; 1996.

3. Oliver E. The first nine books of the Danish history of saxo: Publicatons of the Folklore Society; 1893.

4. Togan ZV. Eski Türkler'de kayakçılık.: Askeri Mecmua; 1939.

5. Amstutz and Max D. The Golden Age of Alpin Skiing, AS Verlag \& Buchkonzept AG, Zurich2010.

6. Hess J. Zur Geschichte des Skis, Vox Romanica1937.

7. Salman H. Eski Türk topluluklarında kayakçılık. Türk Araştırmaları Dergisi, sayı 202008.

8. Olrik J, Raeder H. Saxo Grammaticus, Saxonis Gesta Danorum, Copenhagen1931.

9. Burov and Grigori M. Some Mesolithic wooden artefacts from the site of Vis I in the European North-east of the USSR in Clive Bonsall (Ed) The Mesolithic in Europe, Papers presented at the Third International Symposium. Edinburgh: John Donalds (Eds.); 1985.

10. Schlesinger P. Mathias Zdarsky, the pioneer of alpine skiing. America Alpine J. 1942;3:403-404.

11. Allen J. Zdarsky, Mathias, The father of alpine skiing. Skiing Heritage J. 2008;1:8-14.

12. Öngel HB. Türk kültür tarihinde spor, T.C Kültür Bakanlığı Yayınları, Ankara2001.

13. Jenkis M. First skier, National Geographic. 2013;224(6):85-101.

14. Allen J. Historical dictionary of skiing, Toronto: The Scarecrow Press Inc., Lanham, Playmouth UK2012.

15. Hu H. Turfan ve Komşu bölgelerdeki runik yazıtlarla ilgili epigrafik ve fotogrametrik araştırmalar adlı proje kapsamında 2010 yılında yapılan çalışmalar, Uluslararası Türkçe Edebiyat Kültür Eğitim Dergisi. 2010 42-52.

16. Khazanov MA. Nomads and the outside World, The University of Wisconsin Press 1994.

17. Günal Z. İslam öncesi Türk tarihi ve kültürü, Nobel yayınevi. 2004:7.

18. Ögel B. İslamiyetten önce Türk kültür tarihi: orta asya kaynak ve buluntularına göre, Türk Tarih Kurumu Yay. 2001:56-59.

19. Yılmaz A. Türk kültür terminolojisinde göç kavramı üzerine, Modern Türklük Araştırmaları Dergisi. 2010;7(2):1433. doi: 10.1501/MTAD.7.2010.2.18

20. Gömeç S. Kök Türk Tarihi, Berikan yayınevi, Ankara. 2016:41-66.

21. Hobsbawm E. Introduction inventing traditions, In E. Hobsbawm \& S. Engelhardt (Eds.), Cambridge: The Invention of Tradition Cambridge University Press. 1984:14, 175. doi: 10.1017/CBO9781107295636.001

22. Eberhard W. Çin kaynaklarına göre Türkler ve komşularında spor, Ülkü Dergisi. Mayıs. 1940:209-215.

23. Veaceslav M. he idea of olympism, philosophical concept about The World, Bulletin of the Transilvania University of Braşov Series IX: Sciences of Human Kinetics. 2017;10(1):9-14.

24. Kaşgarlı M. Divânü lügâti't-Türk, çev. Besim Atalay, TDK Yay., cilt I, 4. Baskı, Ankara. 1998:386.

25. Onay İ. İslam öncesi Türk kültüründe avcılığın temelleri ve iktisadi, Askeri, Dini Değeri, Uluslararası Sosyal Araştırmalar Dergisi.8(41):516-525. doi: 10.17719/jisr.20154115037

26. Magnus O. A description of the northern peoples, Hakluyt Society, Rome. 1998:80-224.

27. Emahusen JH. Exercises voon einer Compagnie Schii-Leuffers auf denen Schiihen, Der Winter. 1936;29:90-93. 
28. Stevens S. Olympism and ontological structures of understanding diagoras, International Academic Journal on Olympic Studies. 2017;1:249-226.

29. Allen J. 100 Years of International Skiing, FIS Congress Publishing, Antalya. 2010;2(14):33-34.

30. Petersen P. The Essential cross countyr skier: A step-by-step guide: Ragged Mountain Press, USA; 2000.

31. Schantz O. "The olympic ideal and the Winter Games attitudest towards the Olympic Winter Games in olympic discourses-from Coubertin to Samaranch", Presentation at the Japanese Olympic Academy, Tokyo1997. 